\title{
Dexamethasone-induced intrauterine growth restriction impacts the placental prolactin family, insulin-like growth factor-II and the Akt signaling pathway
}

\author{
Rupasri Ain, Lindsey N Canham and Michael J Soares \\ Institute of Maternal-Fetal Biology and Division of Cancer and Developmental Biology, Departments of Pathology and Laboratory of Medicine, Molecular and \\ Integrative Physiology, and Obstetrics and Gynecology, University of Kansas Medical Center, Kansas City, Kansas 66160, USA \\ (Requests for offprints should be addressed to R Ain, Department of Pathology and Laboratory of Medicine, University of Kansas Medical Center, \\ 3901 Rainbow Blvd, Kansas City, Kansas 66160, USA; Email: arupasri@kumc.edu)
}

\begin{abstract}
Intrauterine growth restriction (IUGR) is a major cause of perinatal death and neonatal morbidity and mortality. There are numerous causes of IUGR. Glucocorticoidinduced IUGR is highly relevant because administration of synthetic glucocorticoids, principally dexamethasone, to women threatened by premature labor is widely used in clinical practice. Fetal growth is directly related to placental growth and development. In this report, we analyzed the effect of dexamethasone on placental development in the rat. Dexamethasone administered between days 13 and 20 of pregnancy not only induced IUGR but also decreased placental mass by approximately 50\%. Impaired placental development was associated with dysregulated placental prolactin (PRL) family and insulin-like growth factor-II (IGF-II) gene expression. Furthermore,
\end{abstract}

there was a significant decrease in the activation of Akt/protein kinase $\mathrm{B}$ in the junctional zone of the placenta, as assessed by the phosphorylation status of Akt and the pro-apoptotic protein $\mathrm{BAD}$, a downstream target of the Akt signaling pathway. Such changes are consistent with increases in indices of apoptosis, including increased cleavage of poly(ADP-ribose) polymerase (PARP) in the junctional zone of the placenta of dexamethasone-treated rats. In summary, dexamethasone-induced IUGR is associated with placental insufficiency, including dysregulated placental hormone/cytokine gene expression and down-regulation of the IGF-II/Akt signaling pathway resulting in increases in indices of placental apoptosis.

Journal of Endocrinology (2005) 185, 253-263

\section{Introduction}

The placenta is an extraembryonic tissue that is situated between maternal and fetal compartments and acts to ensure the normal progression of fetal development. This task is achieved through regulating nutrient and waste transport and modulating the maternal environment through the elaboration of an assortment of hormones, growth factors, and other regulatory molecules. Understanding mechanisms underlying the growth and development of the placenta is paramount to any appreciation of fetal development.

The rat chorioallantoic placenta is organized into two compartments: the junctional zone and the labyrinth zone. The junctional zone is comprised of stem cells and three differentiated cell types: (i) trophoblast giant cells, (ii) spongiotrophoblast cells, and (iii) glycogen cells. Trophoblast giant cells arise by endoreduplication, are situated at the maternal-placental interface, and are one of the major endocrine cells of the placenta (Soares et al. 1996). They synthesize and secrete steroid and peptide hormones. Spongiotrophoblast cells are located immediately beneath the trophoblast giant cell layer and synthesize and secrete peptide hormones. Glycogen cells are a transient cell type embedded among the spongiotrophoblast cells. Beyond their accumulation of glycogen, their biology is not well understood. The labyrinth zone is located at the fetal interface and is comprised of stem cells capable of differentiating into trophoblast giant cells or fusing to form syncytial trophoblast cells. The labyrinthine trophoblast giant cells possess a restricted capacity for hormone production (Soares et al. 1996), whereas syncytial trophoblast cells mediate the transfer of nutrients and wastes between maternal and fetal compartments (Knipp et al. 1999). The composition of the trophoblastic elements within each zone changes through pregnancy. Each trophoblast lineage of the placenta develops specialized functions required for successful pregnancy. Disruptions in trophoblast development can lead to early pregnancy loss or intrauterine growth restriction (IUGR). These represent serious health problems whose etiologies are not sufficiently understood. Differentiation of trophoblast cells can be monitored by their endocrine activities, which include expression of members of the prolactin (PRL) gene family 
(Dai et al. 2002). PRL gene family members have been implicated for their roles in the regulation of maternal adaptation to pregnancy (Soares \& Linzer 2001, Soares 2004).

Synthetic glucocorticoids, including dexamethasone, have been used for over three decades to mature fetal lungs and prevent respiratory distress syndrome in pregnancies where delivery is likely before 34 weeks (Liggins \& Howie 1972, Trainer 2002). Although glucocorticoids promote lung maturation, these actions are not without negative side effects. Exposure to glucocorticoids retards fetal growth in animal models and in humans (Seckl 1994, Gluckman 2001). In rats, fetal-placental exposure to maternally administered glucocorticoids decreases birth weight and placental weight (Benediktsson et al. 1993, Sugden \& Langdown 2001, McDonald et al. 2003). The mechanism underlying the placental growth inhibitory effects of dexamethasone have not been elucidated.

Insulin-like growth factor (IGF)-II is a potential target for glucocorticoid actions on placental development. Evidence exists that glucocorticoids regulate IGF-II expression in a variety of cell types and tissues using both in vitro and in vivo models (Levinovitz \& Norstedt 1989, Cheng et al. 1998, Smink et al. 2002) and IGF-II is viewed as a key autocrine/paracrine placental growth factor (DeChiara et al. 1990, Barker et al. 1993, Constancia et al. 2002). In the mouse, IGF-II null mutations lead to significant IUGR of both the fetus and placenta (DeChiara et al. 1990, Lopez et al. 1996). The rodent placenta possesses all the components of the IGF-II signaling pathway (Zhou \& Bondy 1992, Barker et al. 1993, Lopez et al. 1996).

Both IGF-I and IGF-II act on their target cells via interactions and activation of the IGF receptor type I (IGFR-I) (Nakae et al. 2001). Phosphatidylinositol 3-kinase (PI3-kinase) signaling pathway is a downstream effector of IGFR-I receptor signaling (Kulik \& Weber 1998, Moorehead et al. 2001). PI3-kinase signals through several pleckstrin homology domain containing regulatory proteins, including the Ser/Thr protein kinase, Akt (also called protein kinase B) (Chan et al. 1999, Datta et al. 1999). Akt activation can stimulate changes in gene transcription, cell survival, cell division, and cell differentiation.

In the present report we examined the effects of dexamethasone on the placental phenotype and demonstrate that compromised placental growth following dexamethasone treatment is associated with dysregulated placental PRL family gene expression and downregulation of the IGF-II/Akt signaling pathway leading to increases in indices of placental apoptosis.

\section{Materials and Methods}

\section{Animals and tissue preparation}

Holtzman rats were obtained from Harlan SpragueDawley Inc. (Indianapolis, IN, USA). To obtain timed pregnancies, females were caged overnight with fertile males. The presence of sperm in the vaginal smear was designated as day 0 of pregnancy. On day 13 of pregnancy, pregnant rats were subcutaneously injected with a bolus dose of $100 \mu \mathrm{g}$ dexamethasone acetate (Sigma, St Louis, MO, USA) in $0 \cdot 1 \mathrm{ml} 10 \%$ ethanol. Another group of gestation day 13 pregnant rats was injected with the vehicle only and used as controls. Animals were then anesthetized with halothane, and an alzet osmotic pump (model \# 2 ML1, Durect Corp., Cupertino, CA, USA) was subcutaneously implanted. The osmotic pumps were calibrated to release $200 \mu \mathrm{g}$ dexamethasone acetate $/ \mathrm{kg}$ maternal body weight/day. Control rats received osmotic pumps containing vehicle. Four animals were used in each group. Animals were killed on day 20 of pregnancy. We selected this route and dose of dexamethasone treatment because it was previously demonstrated to cause IUGR in the rat (Benediktsson et al. 1993, Levitt et al. 1996, Sugden \& Langdown 2001). Placental tissues (junctional zone and labyrinth zone) were dissected from pregnant animals. Tissues were snap-frozen in liquid nitrogen for PRL family mini-array and Northern and Western analysis. For in situ hybridization, tissues were frozen in dry ice-cooled heptane. All tissue samples were stored at $-80{ }^{\circ} \mathrm{C}$ until used. The University of Kansas Medical Center Animal Care and Use Committee approved all procedures for handling and experimentation with rodents.

\section{PRL family mini-array assay}

The PRL family mini-array assay, a hybridization-based tool for simultaneously monitoring expression of each member of the rat PRL family (Dai et al. 2002), was used to monitor trophoblast endocrine function. The PRL family mini-array assay was performed as previously described (Dai et al. 2002, Ain et al. 2003). Twenty nanograms PCR-amplified cDNA for each of the members of the rat PRL family were spotted, in duplicate, onto nylon membranes. Membranes were crosslinked and stored at $4{ }^{\circ} \mathrm{C}$ until used. Total RNA was extracted from tissues using TRIzol reagent (Invitrogen, Carlsbad, CA, USA). $\left[\alpha \mathrm{P}^{32}\right]$ dCTP-labeled cDNA probes were generated by reverse transcription using $5 \mu \mathrm{g}$ total RNA. Total RNA was isolated from two pooled and randomly selected placentas per uterus from each animal. A total of four samples were analyzed per treatment group. Probes were purified using micro bio-spin columns (Bio-Rad Laboratories, Richmond, CA, USA). Membrane filters were briefly rinsed with water and pre-hybridized for $2 \mathrm{~h}$ at $42{ }^{\circ} \mathrm{C}$ with $5 \times \operatorname{SSPE}(1 \times \operatorname{SSPE}$ is $0.18 \mathrm{M} \mathrm{NaCl}$, $10 \mathrm{mM} \mathrm{NaH} \mathrm{PO}_{4}, 10 \mathrm{mM}$ EDTA, pH 7.4) containing $5 \times$ Denhardt's reagent, $50 \%$ deionized formamide, $1 \%$ SDS, and salmon sperm DNA $(100 \mu \mathrm{g} / \mathrm{ml})$. Hybridizations were performed overnight with the labeled probes at $42{ }^{\circ} \mathrm{C}$. Membranes were washed once with $2 \times$ SSPE and $0 \cdot 1 \%$ SDS for $30 \mathrm{~min}$ at $42{ }^{\circ} \mathrm{C}$ and twice with 
$0.1 \times$ SSPE and $0.5 \%$ SDS at $60{ }^{\circ} \mathrm{C}$ for $30 \mathrm{~min}$ each. Membranes were then wrapped with plastic wrap and exposed to Kodak Bio-Max film (Kodak, Rochester, NY, USA) for 1-4 h and developed.

\section{Northern blot analysis}

Northern blot analysis was performed as described previously (Faria et al. 1990). Total RNA was extracted from tissues using TRIzol reagent (Invitrogen). Total RNA $(20 \mu \mathrm{g} / \mathrm{lane})$ was resolved in $1 \%$ formaldehyde-agarose gels, transferred to nylon membranes, and crosslinked. Blots were probed with $\alpha \mathrm{P}^{32}$-labeled cDNAs for PRL-like protein-B (PLP-B), PLP-C, placental lactogen-Iv (PL-Iv), PL-II (Dai et al. 2002) and IGF-II. Glyceraldehyde-3'phosphate dehydrogenase (G3 PDH) cDNA was used to evaluate the integrity and equal loading of RNA samples. At least three different tissue samples from three different animals were analyzed with each probe.

\section{In situ hybridization}

In situ hybridization was performed as described previously (Ain et al. 2003, 2004). Ten-micron cryosections of tissues were prepared and stored at $-80{ }^{\circ} \mathrm{C}$ until used. Plasmids containing cDNAs for rat PLP-C, PL-II and IGF-II were used as templates to synthesize sense and anti-sense digoxigenin-labeled riboprobes according to the manufacturer's instructions (Roche Molecular Biochemicals, Indianapolis, IN, USA). Tissue sections were air dried and fixed in ice-cold 4\% paraformaldehyde in phosphatebuffered saline (PBS) for $15 \mathrm{~min}$. Pre-hybridization was carried out in a humidified chamber at $50^{\circ} \mathrm{C}$ in $5 \times$ SSC (standard saline citrate), $50 \%$ deionized formamide, $1 \times$ Denhardt's reagent, $10 \%$ dextran sulfate and salmon sperm DNA $(100 \mu \mathrm{g} / \mathrm{ml})$. Hybridizations were performed in the same incubation conditions overnight. Slides were washed in $2 \times \mathrm{SSC}$ at room temperature for $30 \mathrm{~min}$ followed by treatment with RNase-A (100 ng/ml) and additional washes with $2 \times \mathrm{SSC}$ for $30 \mathrm{~min}$ at room temperature, $2 \times \operatorname{SSC}$ for $1 \mathrm{~h}$ at $65^{\circ} \mathrm{C}$, and $0.1 \times$ SSC for $1 \mathrm{~h}$ at $65{ }^{\circ} \mathrm{C}$. Tissue samples were then blocked for $30 \mathrm{~min}$ and incubated with alkaline phosphatase-conjugated antidigoxigenin antibody (1:500) in blocking buffer (Roche Molecular Biochemicals) for $2 \mathrm{~h}$ at room temperature. Slides were then washed and detection was performed using nitro blue tetrazolium $(250 \mu \mathrm{g} / \mathrm{ml})$ and 5bromo-4-chloro-3-indolyl-phosphate $(225 \mu \mathrm{g} / \mathrm{ml}$; Roche Molecular Biochemicals).

\section{Western blot analysis}

Tissues were homogenized in a Tris saline buffer $(50 \mathrm{mM}$ Tris, $150 \mathrm{mM} \mathrm{NaCl}, \mathrm{pH} \mathrm{7 \cdot 4}$, containing 1\% NP-40, $1 \mathrm{mM}$ EDTA, $0 \cdot 1 \mathrm{mg} / \mathrm{ml}$ PMSF, and a protease inhibitor cocktail; Sigma). Samples were then centrifuged and the supernatants collected. Protein concentrations were determined for each sample using the Bio-Rad DC protein assay (Bio-Rad). Proteins were separated by SDS-PAGE under reducing conditions and were then transferred to nitrocellulose membranes (Schleicher \& Schuell, Keene, $\mathrm{NH}$, USA). The blots were then incubated for one hour in blocking solution (5\% nonfat dry milk in Tris-buffered saline containing $0 \cdot 1 \%$ Tween 20, TBST) and then overnight with rabbit polyclonal antibodies obtained from Cell Signaling (Beverly, MA, USA) to phosphorylatedAkt (Ser ${ }^{473}$, cat. no. 9271), Akt (cat. no. 9272), phosphorylated-BAD (Ser ${ }^{136}$, cat. no. 9295), BAD (cat. no. 9292), or poly(ADP-ribose) polymerase (PARP, cat. no. 9542). Antibodies were diluted to 1:1000 either in blocking solution or in TBST containing $5 \%$ bovine serum albumin (BSA). After washing the membranes in TBST, the blots were incubated with horseradish peroxidaseconjugated goat anti-rabbit IgG (Cell Signaling) diluted 1:2000 in blocking solution for one hour at room temperature. After washing with TBST, bound antibodies were detected by chemiluminescence (ECL kit; Amersham Pharmacia Biotech, Piscataway, NJ, USA). Blots were then stripped using stripping buffer (Pierce Chemical Co., Rockford, IL, USA) and re-probed using $\beta$-actin antibody (Sigma) using the above protocol.

\section{Statistical analysis}

The data were analyzed by analysis of variance. The source of variation from significant $\mathrm{F}$ ratios was determined with the Newman-Keuls multiple comparison test (Keppel 1973).

\section{Results}

Maternal dexamethasone administration influences fetal and placental development and placental hormone production

Similar to previous reports, dexamethasone administration during the last third of gestation resulted in both fetal (Fig. 1A, $P<0 \cdot 01)$ and placental growth restriction (Fig. 1B, $P<0 \cdot 01$, and Fig. 1C). Additionally, maternal body weight gain was affected by dexamethasone treatment (control, $59 \pm 7 \mathrm{~g}$ versus dexamethasone, $34 \pm 3 \mathrm{~g}$, $P<0 \cdot 01)$. Dexamethasone treatment did not affect litter size (number of fetuses) or fetal viability.

The junctional zone of the chorioallantoic placenta is the primary source of members of the PRL family of hormones/cytokines during the last week of pregnancy, whereas the labyrinth zone makes a lesser contribution. The PRL family mini-array hybridization assay was used to survey placental responses to maternal dexamethasone exposure. Maternal dexamethasone treatment resulted in the dysregulation of PRL family gene expression in both 

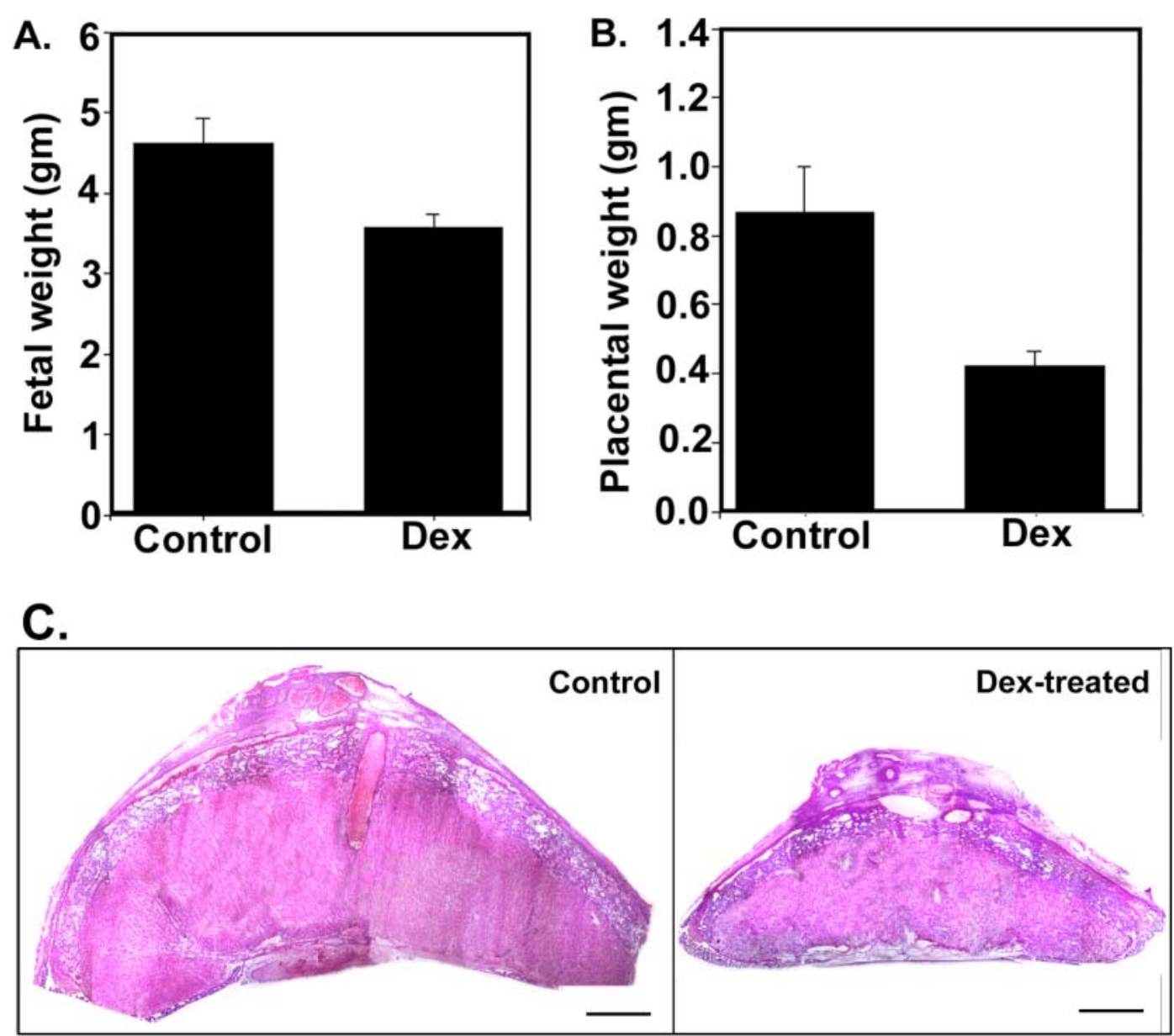

Figure 1 Effects of dexamethasone (Dex) on fetal and placental development. Fetuses and placentas were dissected on day 20 of gestation from control and Dex-treated rats. (A) Fetal weights decreased by $23 \%$ in the Dex-treated group as compared with control $(P<0 \cdot 01)$. (B) Placental weights decreased by $51 \%$ in the Dex-treated group as compared with control $(P<0 \cdot 01)$. (C) Hematoxylin and eosin staining of gestation day 20 placentas from control and Dex-treated animals. Scale bars, $1 \mathrm{~mm}$.

regions of the chorioallantoic placenta (Fig. 2). In general, if affected, PRL family gene expression was inhibited in the junctional zone, whereas PRL family gene expression was stimulated in the labyrinth zone. The inhibitory effect of dexamethasone on junctional zone gene expression was best exemplified by monitoring PLP-B mRNA levels, whereas in the labyrinth zone PLP-C mRNA showed the most dramatic response (Fig. 2). Northern blot analyses were used to further validate the expression of the PRL gene family in the placenta (Fig. 3A). Maternal dexamethasone treatment dramatically inhibited junctional zone PLP-B transcripts. PL-II showed modest changes in either placental zone following dexamethasone treatment (Fig. 3A, B and C). The influence of dexamethasone on the expression of PLP-C transcripts was dependent on the placental zone. Dexamethasone treatment had minimal effects on PLP-C mRNA levels in the junctional zone, in contrast to a dramatic upregulation of labyrinthine PLP-C mRNA levels (Figs 2 and 3).

The expression of PLP-C in the labyrinth zone is an aberration, which prompted an investigation of the cellular site of PLP-C expression. Tissue distributions of PLP-C mRNAs were monitored by in situ hybridization (Fig. 3D). Expression of PL-II was used as a control as its expression was not substantially altered by dexamethasone treatment and is restricted to trophoblast giant cells of the junctional and labyrinth zones. PLP-C transcripts were not detectable by in situ hybridization in the labyrinth zone of the placenta from the control group. Maternal dexamethasone treatment resulted in the detection of colonies of PLP-C mRNA-positive cells in the labyrinth zone. Morphologically, the cells in these colonies resembled spongiotrophoblast cells of the junctional zone. In summary, maternal dexamethasone 

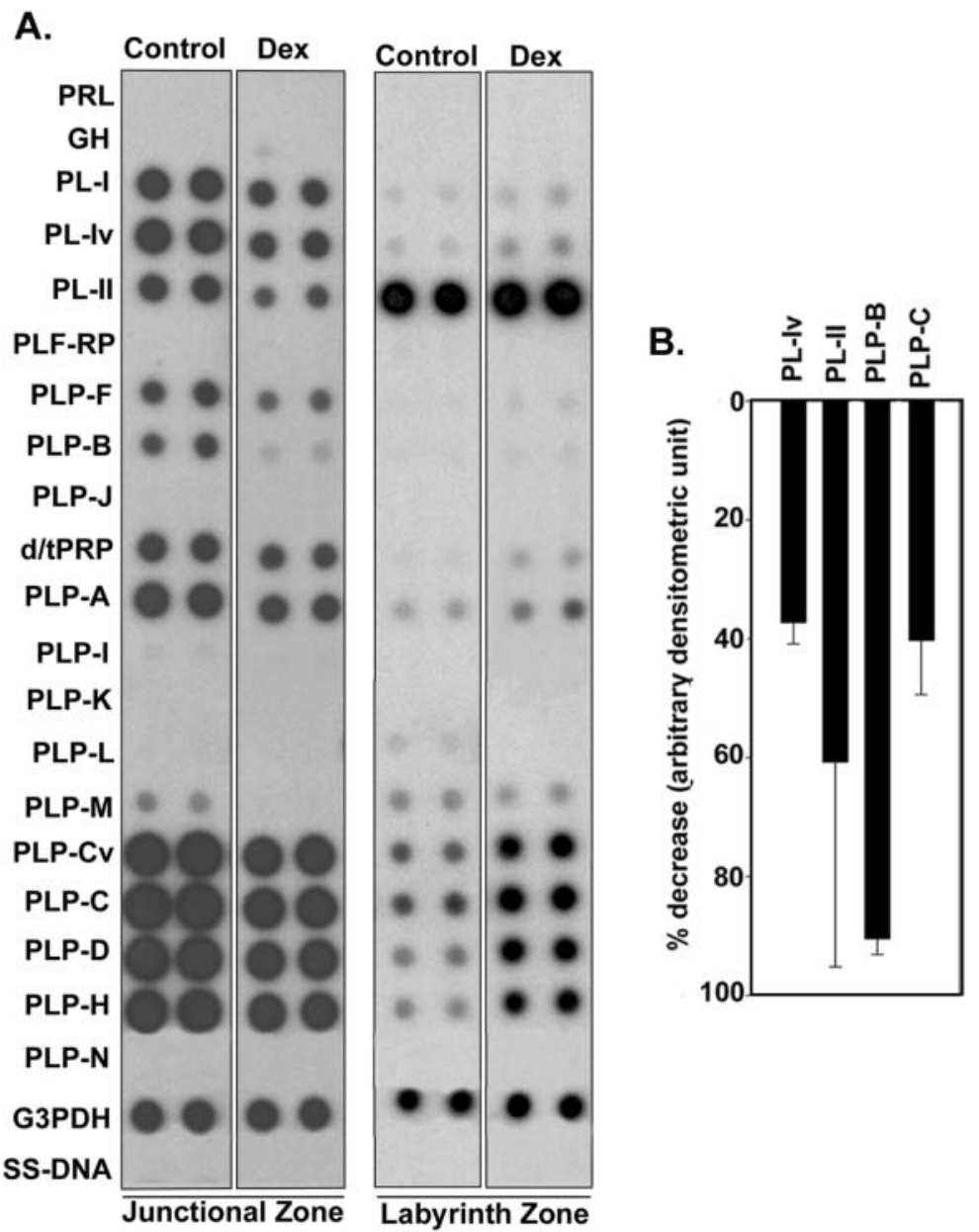

C.

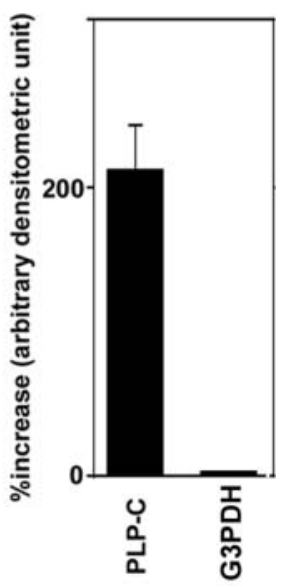

Figure 2 Impact of in vivo dexamethasone (Dex) treatment on PRL gene family expression in placentas from gestation day 20. (A) Representative PRL family mini-array analyses of RNAs isolated from the junctional and labyrinth zones of the chorioallantoic placenta. Total RNA samples were isolated on day 20 of gestation, radiolabeled by reverse-transcription, and used as hybridization probes for rat PRL family mini-arrays. Glyceraldehyde-3'-phosphate dehydrogenase (G3 PDH) was used as control. Additional abbreviations: PRL, prolactin; $\mathrm{GH}$, growth hormone; PL, placental lactogen; PLF-RP, proliferin-related protein; PLP, PRL-like protein; $\mathrm{d} /$ tPRP, decidual/trophoblast PRL-related protein. (B and C) Densitometric analyses of PRL family mini-arrays (based on 3-4 replicate experiments) for selected PRL family genes - (B) junctional zone, (C) labyrinth zone.

affected placental development and hormone/cytokine gene expression.

Dexamethasone regulates IGF-II $m R N A$ expression by the placenta

In the next series of experiments, we sought to account for the intrauterine placental growth retardation. Initially, we examined the effect of maternal dexamethasone treatment on placental IGF-II expression. Northern blot analysis showed that there was a prominent decrease in IGF-II mRNA concentrations in junctional zones from dexamethasone-treated animals (Fig. 4A and B). Maternal dexamethasone treatment had only modest effects on
IGF-II expression in the labyrinth zone (Fig. 4A, B). In situ hybridization of placental IGF-II mRNA expression corroborated the Northern blot analysis (Fig. 4C). IGF-II signaling is critical to placental development (DeChiara et al. 1990, Barker et al. 1993, Constancia et al. 2002). Thus, maternal dexamethasone-associated placental growth restriction may be mediated, at least in part, by decreased placental IGF-II.

Dexamethasone down-regulates Akt signaling pathway and increases indices of placental apoptosis

IGFs act, at least in part, through the PI3-kinase/Akt signaling pathway (Kulik \& Weber 1998, Moorehead et al. 2001). 
A.
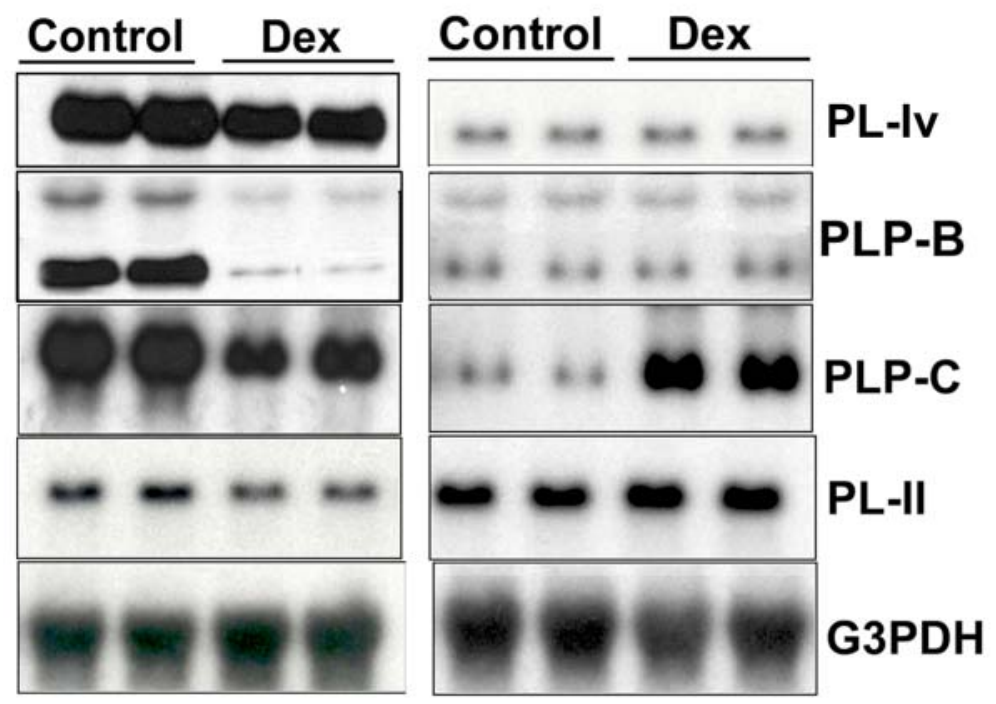

B.

C.

\section{Junctional Zone Labyrinth Zone}
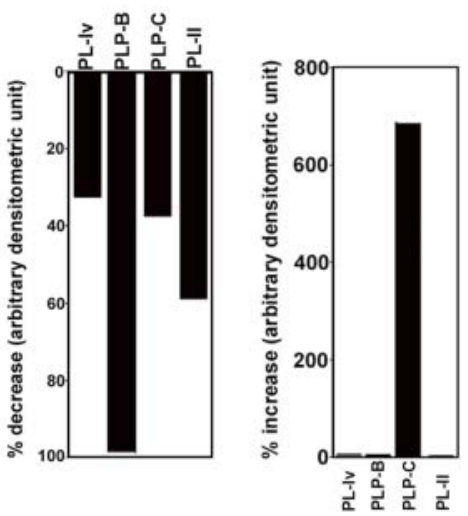

D.

\section{Control Dexamethasone}

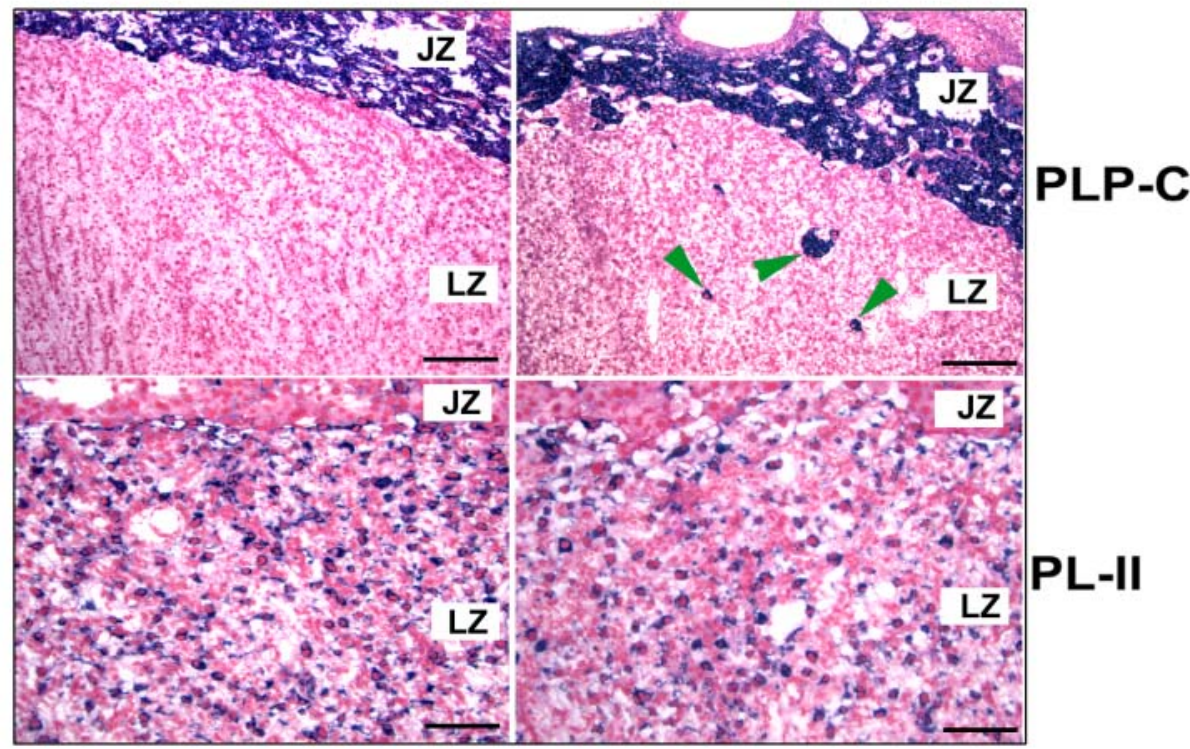

Figure 3 Expression of mRNAs for PL-Iv, PLP-B, PLP-C and PL-II in placentas from dexamethasone (Dex)-treated and control rats. (A) Northern blot analysis using total RNA isolated from gestational day 20 junctional and labyrinth zones of chorioallantoic placentas from control and Dex-treated groups. RNAs were fractionated by formaldehyde-agarose gel electrophoresis, transferred to nylon, and hybridized to ${ }^{32}$ P-labeled cDNA probes for PL-IV, PLP-B, PLP-C, PL-II or G3 PDH. G3 PDH was used to evaluate the integrity of the RNA samples and as a control for gel loading. (B and C) Densitometric analyses of mRNA levels - (B) junctional zone, (C) labyrinth zone. (D) In situ localization of PLP-C and PL-II mRNAs in placentas from control and dexamethasone-treated rats. Ten-micron cryosections of the tissues were prepared and hybridized to digoxigenin-labeled anti-sense and sense (data not shown) probes for PLP-C and PL-II. Green arrowheads indicate PLP-C positive cells in the labyrinth zone. Scale bars, $250 \mu \mathrm{m}$. JZ, junctional zone; LZ, labyrinth zone. 

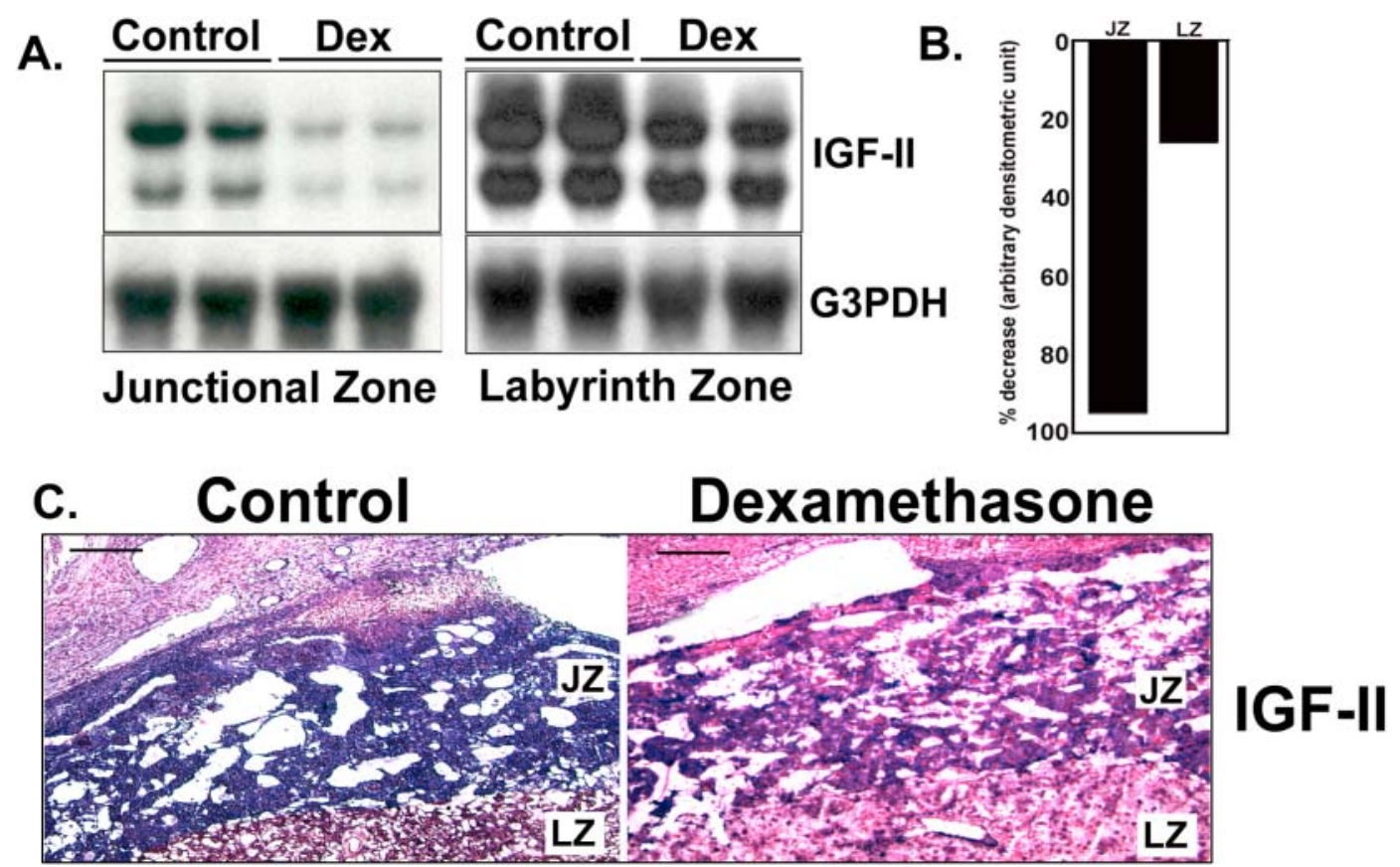

Figure 4 Expression of IGF-II mRNA in placentas from dexamethasone (Dex)-treated and control rats. (A) Northern blot analysis using total RNA isolated from gestational day 20 junctional and labyrinth zones of chorioallantoic placentas from control and dexamethasone-treated groups. RNA was fractionated by formaldehyde-agarose gel electrophoresis, transferred to nylon, and hybridized to ${ }^{32}$ P-labeled cDNA probes for IGF-II or G3 PDH. G3 PDH was used to evaluate the integrity of the RNA samples and as a control for gel loading. (B) Densitometric analyses of IGF-II mRNA levels. (C) In situ localization of IGF-II mRNA in rat placentas from control and dexamethasone-treated groups. Ten-micron cryosections of the tissues were prepared and hybridized to digoxigenin-labeled anti-sense and sense (data not shown) probes for IGF-II. Scale bars, $250 \mu \mathrm{m}$. JZ, junctional zone; LZ, labyrinth zone.

Thus, we examined the effects of maternally administered dexamethasone on placental Akt signaling. Junctional zone lysates from control and dexamethasone-treated groups were subjected to immunoblot analysis. Activation of the Akt pathway is associated with phosphorylation of Akt on Ser ${ }^{473}$. Maternal dexamethasone treatment led to a significant decrease in Akt activation (Fig. 5A and B). Total Akt protein expression was not significantly affected by the treatment (Fig. 5A). We next examined a downstream effector of Akt, BAD, a known regulator of apoptosis. Phosphorylation of BAD on $\operatorname{Ser}^{136}$ by activated Akt prevents apoptosis. Consistent with the deactivation of Akt, we observed that maternal dexamethasone treatment also resulted in decreased phosphorylated BAD without affecting total BAD protein (Fig. 5C and D). These results suggest that pathways preventing apoptosis in the junctional zone might be disrupted in the dexamethasone-exposed placentas. Thus, we monitored the integrity of the junctional zone using cleaved PARP as a measure of apoptosis (Lazebnik et al. 1994). As shown in Fig. 5E and F, dexamethasone treatment was associated with an increased accumulation of the $89-\mathrm{kDa}$ PARP cleavage product when compared with controls. Blots were stripped and re-probed with $\beta$-actin to show that equal amounts of protein were loaded in each lane (Fig. 5E). Maternally administered dexamethasone leads to attenuated placental Akt signaling and increases in at least one measure of placental apoptosis, PARP cleavage.

\section{Discussion}

In most species, size of the fetus is proportional to placental size. When the size of the placenta is restricted, as in maternal malnutrition or compromised placental blood flow, the fetus is also often growth restricted (Price et al. 1992). A poorly developed or inefficiently functioning placenta is associated with a reduction in birth weight. In this report, we investigated the effect of maternally administered dexamethasone on placental development and function. We chose a dose and route of dexamethasone administration that reproducibly induces IUGR in rats (Benediktsson et al. 1993, Sugden \& Langdown 2001, McDonald et al. 2003).

Pregnancy-dependent adjustments in maternal and fetal compartments are orchestrated by the endocrine function 

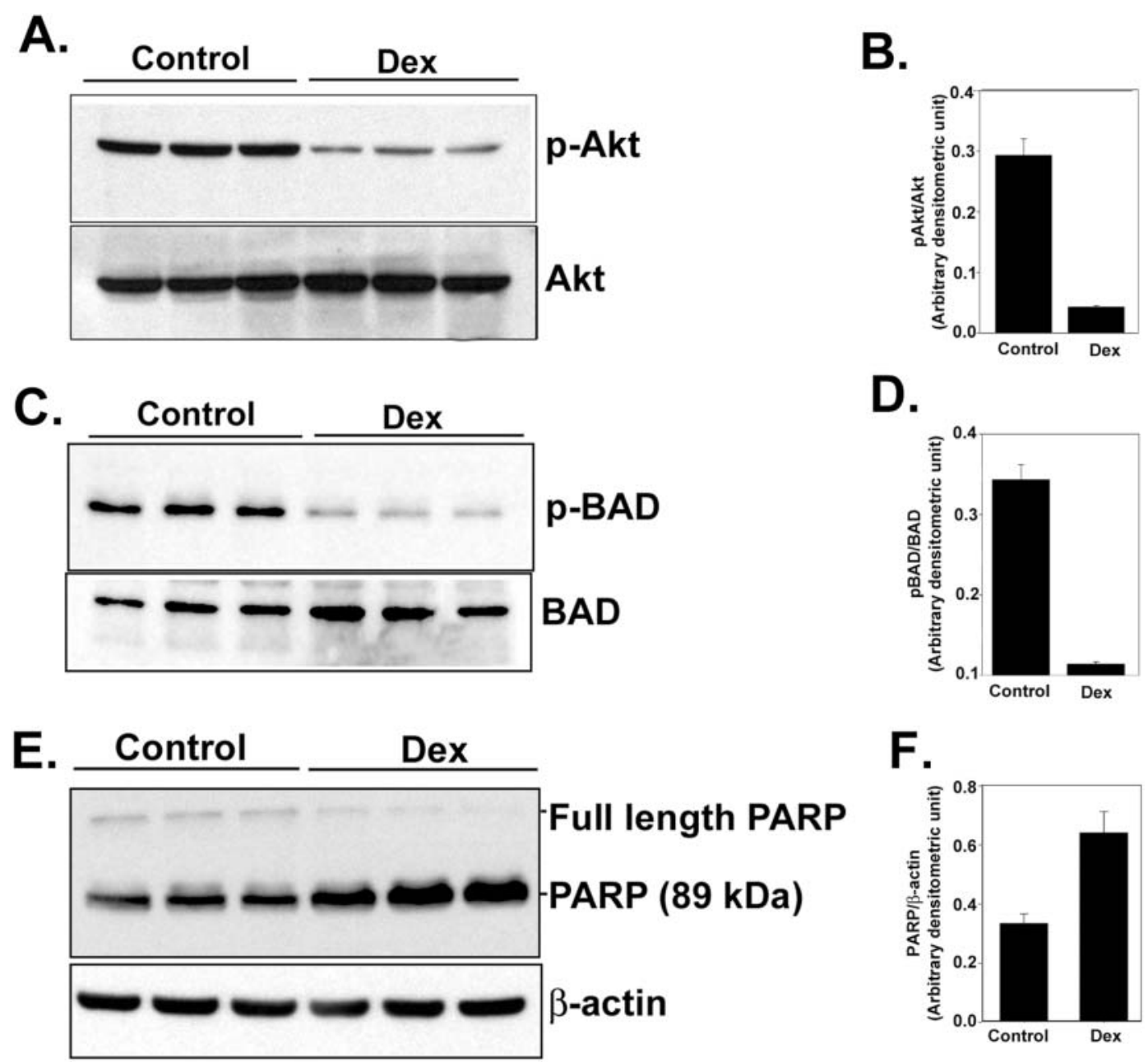

Figure 5 Dexamethasone (Dex) treatment decreases Akt and BAD phosphorylation and increases cleavage of PARP. Western blot analysis of phospho (p)-Akt and Akt (A), phospho (p)-BAD and BAD (C) in junctional zone placental tissues from control and Dex-treated animals. Thirty micrograms total protein were loaded in each lane. Lanes 1-3, junctional zone samples from three different control rats; lanes $4-6$, junctional zone samples from three different Dex-treated rats. All samples were harvested on day 20 of gestation. Densitometric measurements for phospho-Akt/Akt are presented in (B) and for phospho-BAD/BAD in (D). (E) Western blot analysis of PARP in junctional zone placental tissues from control and Dex-treated animals. Twenty micrograms total protein were loaded in each lane. Lanes 1-3, samples from three different control rats; lanes 4-6, samples from three different Dex-treated rats. All samples were harvested on day 20 of gestation. Blots were stripped and re-probed with $\beta$-actin antibody to ensure equal loading. (F) Densitometric measurements for the PARP and $\beta$-actin Western blotting.

of trophoblast cells (Soares et al. 1996). As trophoblast cells differentiate they acquire the capacity to produce hormones, cytokines, and growth factors, including members of the PRL family (Soares \& Linzer 2001, Soares 2004). Maternal dexamethasone treatment resulted in the dysregulation of PRL family gene expression and compromised placental development. Dexamethasone negatively impacted production of members of the PRL family associated with the junctional zone, especially the spongiotrophoblast-specific PLP-B mRNAs. In contrast, the effect of dexamethasone on the labyrinth zone was highlighted by a marked increase in expression of PLP-C.
PLP-C is not normally expressed in the labyrinth zone (Dai et al. 2002). Labyrinthine PLP-C was attributed to spongiotrophoblast-like cellular colonies inappropriately developing in the labyrinth zone of the dexamethasonetreated rats. PRL family hormones/cytokines participate in the regulation of maternal and fetal adaptations to pregnancy (Soares \& Linzer 2001, Soares 2004). Whether dysregulated PRL family gene expression patterns contribute directly or indirectly to the placental and/or fetal IUGR remain to be determined.

Disruptions in spongiotrophoblast cell development may be central to the placental endocrine phenotype induced 
by maternal dexamethasone treatment. Interestingly, dysmorphic development of spongiotrophoblast cells is also a characteristic of interspecies hybrid and cloned placentas (Rogers \& Dawson 1970, Zechner et al. 1996, 1997, Kurz et al. 1999, Tanaka et al. 2001). Abnormalities in genomic imprinting are implicated in these placental pathologies (Zechner et al. 2002, Schutt et al. 2003, Ohgane et al. 2004, Shi et al. 2004, Singh et al. 2004). There is some evidence for imprinting among members of the placental PRL family in Peromyscus (Vrana et al. 2001); however, experimentation on imprinting within the rat PRL family locus has not been reported. Imprinting is fundamental to the regulation of IGF-II, which was also affected by maternal dexamethasone treatment in our study. IGF-II is one of many genes exhibiting allele-specific expression with an impact on placental development. A more generalized influence of maternal dexamethasone treatment on the process of genomic imprinting in the developing placenta and fetus has not been reported.

The effect of dexamethasone on placental IGF-II expression provides for a logical explanation of the IUGR. Our data showed that maternal dexamethasone-induced IUGR was associated with decreased expression of IGF-II by the junctional zone of the placenta. IGF-II null mutations in mice are known to cause fetal and placental growth restriction (DeChiara et al. 1990).

IGFs affect cellular function, at least in part, through the PI3-kinase pathway (Kulik \& Weber 1998, Moorehead et al. 2001). Akt is one of the principal downstream mediators of PI3-kinase action (Datta et al. 1999, Richards 2001, Downward 2004). We observed that maternal dexamethasone treatment was associated with decreased placental Akt activation. Of the three Akt family members, Akt1 is most abundantly expressed in the placenta (Kamei et al. 2002, Yang et al. 2003). Akt1 null mice are growth restricted due, in part, to placental insufficiency (Chen et al. 2001, Cho et al. 2001, Yang et al. 2003). Our findings are also consistent with earlier studies showing that the PI3-kinase/Akt pathway modulates trophoblast cell endocrine differentiation, including expression of the PRL gene family (Kamei et al. 2002).

Akt impacts an array of cellular processes, including cell survival (Chen et al. 2001, Vivanco \& Sawyers 2002, Yang et al. 2003, Downward 2004, Brazil et al. 2004) and influences cell survival, in part, through phosphorylation of the proapoptotic protein, BAD (Datta et al. 1997, 1999, 2002, del Peso et al. 1997, Downward 1999, Bergmann 2002, Jiang et al. 2003). Phosphorylation of BAD prevents its association with $\mathrm{Bcl}-2$ or $\mathrm{Bcl}-\mathrm{X}_{\mathrm{L}}$, leaving these proteins free to exert their antiapoptotic function (Yang et al. 1995, Zha et al. 1996). In our experimentation, maternal dexamethasone treatment diminished junctional zone placental Akt activation, which was associated with decreased BAD phosphorylation and increased PARP cleavage, an indicator of apoptosis. These findings are consistent with earlier experimentation showing maternal dexamethasone increases apoptosis, as measured by TUNEL activity, within the junctional zone of the rat placenta (Waddell et al. 2000).

In summary, maternal dexamethasone-induced IUGR is associated with placental insufficiency, dysregulation of placental hormone production, and inhibition of placental IGF-II and Akt signaling. Based on the literature presented above, it is reasonable to presume that some or all of these events may be linked; however, establishing causal relationships will require additional experimentation.

\section{Funding}

This work was supported by grants from the National Institutes of Health (HD20676, HD39878), the Hall Family Foundation (to M J S) and the Phillip S Astrowe Trust (to R A). The authors declare that there is no conflict of interest that would prejudice the impartiality of this scientific work.

\section{References}

Ain R, Canham LN \& Soares MJ 2003 Gestation stage-dependent intrauterine trophoblast cell invasion in the rat and mouse: novel endocrine phenotype and regulation. Developmental Biology 260 176-190.

Ain R, Trinh M-L \& Soares MJ 2004 Interleukin-11 signaling is required for the differentiation of natural killer cells at the maternal-fetal interface. Developmental Dynamics 231 700-708.

Barker DJP, Martyn CN, Osmond C, Hales CN \& Fall CHD 1993 Growth in utero and serum cholesterol concentrations in adult life. British Medical Journal 307 1524-1527.

Benediktsson R, Lindsay RS, Noble J, Seckl JR \& Edwards CR 1993 Glucocorticoid exposure in utero: new model for adult hypertension. Lancet 341 339-341.

Bergmann A 2002 Survival signaling goes BAD. Developmental Cell 3 607-608.

Brazil DP, Yang ZZ \& Hemmings BA 2004 Advances in protein kinase B signalling: AKTion on multiple fronts. Trends in Biochemical Sciences $29233-242$.

Chan TO, Rittenhouse SE \& Tsichlis PN 1999 AKT/PKB and other D3 phosphoinositide-regulated kinases: kinase activation by phosphoinositide-dependent phosphorylation. Annual Review of Biochemistry 68 965-1014.

Chen WS, Xu P-Z, Gottlob K, Chen M-L, Sokol K, Shiyanova T, Roninson I, Weng W, Suzuki R, Tobe K, Kadowaki T \& Hay N 2001 Growth retardation and increased apoptosis in mice with homozygous disruption of the akt1 gene. Genes and Development 15 2203-2208.

Cheng SL, Zhang SF, Mohan S, Lecanda F, Fausto A, Hunt AH, Canalis E \& Aviolo LV 1998 Regulation of insulin-like growth factors I and II and their binding proteins in human bone marrow stromal cells by dexamethasone. Journal of Cellular Biochemistry 71 449-458.

Cho H, Thorvaldsen JL, Chu Q, Feng F \& Birnbaum MJ 2001 $\mathrm{Akt} 1 / \mathrm{PKB} \alpha$ is required for normal growth but dispensable for maintenance of glucose homeostasis in mice. Journal of Biological Chemistry 276 38349-38352.

Constancia M, Hemberger M, Hughes J, Dean W, Ferguson-Smith A, Fundele R, Stewart F, Kelsey G, Fowden A, Sibley C \& Reik W 2002 Placenta-specific IGF-II is a major modulator of placental and fetal growth. Nature 417 945-948. 
Dai G, Lu L, Tang S, Peal MJ \& Soares MJ 2002 The prolactin family mini-array: a tool for evaluating uteroplacental/trophoblast endocrine phenotype. Reproduction 124 755-765.

Datta SR, Dudek H, Tao X, Masters S, Gotoh H, Fu Y \& Greenberg ME 1997 Akt phosphorylation of BAD couples survival signals to the cell-intrinsic death machinery. Cell 91 231-241.

Datta SR, Brunet A \& Greenberg ME 1999 Cellular survival: a play in three akts. Genes and Development 13 2905-2927.

Datta SR, Ranger AM, Lin MZ, Sturgill JF, Ma YC, Cowan CW, Dikkes P, Korsmeyer SJ \& Greenberg ME 2002 Survival factor-mediated BAD phosphorylation raises the mitochondrial threshold for apoptosis. Developmental Cell 3 631-643.

DeChiara TM, Efstratiadis A \& Robertson EJ 1990 A growthdeficiency phenotype in heterozygous mice carrying an insulin-like growth factor II gene disrupted by targeting. Nature 345 78-80.

Downward J 1999 How BAD phosphorylation is good for survival. Nature Cell Biology 1 E33-E35.

Downward J 2004 PI 3-kinase, Akt and cell survival. Seminars in Cell and Developmental Biology 15 177-182.

Faria TN, Deb S, Kwok SCM, Talamantes F \& Soares MJ 1990 Ontogeny of placental lactogen-I and placental lactogen-II expression in the developing rat placenta. Developmental Biology 141 279-291.

Gluckman PD 2001 Nutrition, glucocorticoids, birth size and adult disease. Endocrinology 142 1689-1691.

Jiang K, Zhong B, Ritchey C, Gilvary DL, Hong-Geller E, Wei S \& Djeu JY 2003 Regulation of Akt-dependent cell survival by Syk and Rac. Blood 101 236-244.

Kamei T, Jones SR, Chapman BM, McGonigle KL, Dai G \& Soares MJ 2002 The phosphatidyl 3-kinase signaling pathway modulates the endocrine differentiation of trophoblast cells. Molecular Endocrinology 16 1469-1481.

Keppel G 1973 Design and analysis. Englewood Cliffs, NJ: Prentice Hall.

Knipp GT, Audus KL \& Soares MJ 1999 Nutrient transport across the placenta. Advances in Drug Delivery Reviews 38 41-58.

Kulik G \& Weber MJ 1998 Akt-dependent and -independent survival signaling pathways utilized by insulin-like growth factor I. Molecular and Cellular Biology 18 6711-6718.

Kurz H, Zechner U, Orth A \& Fundele R 1999 Lack of correlation between placenta and offspring size in mouse interspecific crosses. Anatomy and Embryology 200 335-343.

Lazebnik YA, Kaufmann SH, Desnoyers S, Poirier GG \& Earnshaw WC 1994 Cleavage of poly(Adp-ribose) polymerase by A proteinase with properties like ice. Nature 371 346-347.

Levinovitz A \& Norstedt G 1989 Developmental and steroid hormonal regulation of insulin-like growth factor expression. Molecular Endocrinology 3 797-804.

Levitt NS, Lindsay RS, Holmes MC \& Seckl JR 1996

Dexamethasone in the last week of pregnancy attenuates hippocampal glucocorticoid receptor gene expression and elevates blood pressure in the adult offspring in the rat. Neuroendocrinology 64 412-418.

Liggins GC \& Howie RN 1972 A controlled trial of antepartum glucocorticoids treatment for prevention of the respiratory distress syndrome in premature infants. Pediatrics 50 515-525.

Lopez MF, Dikkes P, Zurakowski D \& Villa-Komaroff L 1996 Insulin-like growth factor II affects the appearance and glycogen content of glycogen cells in the murine placenta. Endocrinology 137 2100-2108.

McDonald TJ, Franko KL, Brown JM, Jenkins SL, Nathanielsz PW \& Nijland MJ 2003 Betamethasone in the last week of pregnancy causes fetal growth retardation but not adult hypertension in rats. Journal of the Society for Gynecologic Investigation 10 469-473.

Moorehead RA, Fata JE, Johnson MB \& Khokha R 2001 Inhibition of mammary epithelial apoptosis and sustained phosphorylation of Akt/PKB in MMTV-IGF-II transgenic mice. Cell Death Differentiation 8 16-29.
Nakae J, Kido Y \& Accili D 2001 Distinct and overlapping functions of insulin and IGF-I receptors. Endocrine Reviews 22 818-835.

Ohgane J, Wakayama T, Senda S, Yamazaki Y, Inoue K, Ogura A, Marh J, Tanaka S, Yanagimachi R \& Shiota K 2004 The Sall3 locus is an epigenetic hotspot of aberrant DNA methylation associated with placentomegaly of cloned mice. Genes and Cells 9 253-260.

del Peso L, Gonzalez-Garcia M, Page C, Herrera R \& Nunez G 1997 Interleukin-3-induced phosphorylation of BAD through the protein kinase Akt. Science 278 687-689.

Price WA, Rong L, Stiles AD \& D’Ercole AJ 1992 Changes in IGF-I and -II, IGF binding protein, and IGF receptor transcript abundance after uterine artery ligation. Pediatric Research 32 291-295.

Richards JS 2001 New signaling pathways for hormones and cyclic adenosine $3^{\prime}, 5^{\prime}$-monophosphate action in endocrine cells. Molecular Endocrinology 15 209-218.

Rogers JF \& Dawson WD 1970 Foetal and placental size in a Peromyscus species cross. Journal of Reproduction and Fertility 21 255-262.

Seckl JR 1994 Glucocorticoids and small babies. Quarterly Journal of Medicine 87 259-262.

Schutt S, Florl AR, Shi W, Hemberger M, Orth A, Otto S, Schulz WA \& Fundele RH 2003 DNA methylation in placentas of interspecies mouse hybrids. Genetics 165 223-228.

Shi W, Lefebvre L, Yu Y, Otto S, Krella A, Orth A \& Fundele R 2004 Loss-of-imprinting of Peg1 in mouse interspecies hybrids is correlated with altered growth. Genesis 39 65-72.

Singh U, Fohn LE, Wakayama T, Ohgane J, Steinhoff C, Lipkowitz B, Schulz R, Orth A, Ropers HH, Behringer RR, Tanaka S, Shiota K, Yanagimachi R, Nuber UA \& Fundele R 2004 Different molecular mechanisms underlie placental overgrowth phenotypes caused by interspecies hybridization, cloning, and Esx1 mutation. Developmental Dynamics 230 149-164.

Smink JJ, Koedam JA, Koster JG \& van Buul-Offers SC 2002 Dexamethasone-induced growth inhibition of procine growth plate chondrocytes is accompanied by changes in levels of IGF axis components. Journal of Endocrinology 174 343-352.

Soares MJ 2004 The prolactin and growth hormone families: pregnancy-specific hormones/cytokines at the maternal-fetal interface. Reproductive Biology and Endocrinology 251 [http://www.rbej.com/content/2/1/51]

Soares MJ \& Linzer DIH 2001 Rodent prolactin family and pregnancy. In Prolactin, pp 139-167. Ed ND Horseman. Norwell, MA: Kluwer Academic Publishers.

Soares MJ, Chapman BM, Rasmussen CA, Dai G, Kamei T \& Orwig KE 1996 Differentiation of trophoblast endocrine cells. Placenta 17 277-289.

Sugden MC \& Langdown ML 2001 Possible involvement of PKC isoforms in signaling placental apoptosis in intrauterine growth retardation. Molecular and Cellular Endocrinology 185 119-126.

Tanaka S, Oda M, Toyoshima Y, Wakayama T, Tanaka M, Yoshida N, Hattori N, Ohgane J, Yanagimachi R \& Shiota K 2001 Placentomegaly in cloned mouse concepti caused by expansion of the spongiotrophoblast layer. Biology of Reproduction 65 1813-1821.

Trainer PJ 2002 Corticosteroids and pregnancy. Seminars in Reproductive Medicine 20 375-380.

Vivanco I \& Sawyers CL 2002 The phosphatidylinositol 3-kinase-AKT pathway in human cancer. Nature Reviews Cancer 2 489-501.

Vrana PB, Matteson PG, Schmidt JV, Ingram RS, Joyce A, Prince KL, Dewey MJ \& Tilghman SM 2001 Genomic imprinting of a placental lactogen gene in Peromyscus. Development, Genes \& Evolution 211 523-532.

Waddell BJ, Hishesh S, Dharmarajan AM \& Burton PJ 2000 Apoptosis in rat placenta is zone-dependent and stimulated by glucocorticoids. Biology of Reproduction 63 1913-1917. 
Yang E, Zha J, Jockel J, Boise LH, Thompson CB \& Korsmeyer SJ $1995 \mathrm{Bad}$, a heterodimeric partner for $\mathrm{Bcl}-\mathrm{XL}$ and $\mathrm{Bcl}-2$, displaces Bax and promotes cell death. Cell 80 285-291.

Yang Z-Z, Tschopp O, Hemmings-Mieszczak M, Feng J, Brodbeck D, Perentes E \& Hemmings BA 2003 Protein kinase B $\alpha /$ Akt1 regulates placental development and fetal growth. Journal of Biological Chemistry 278 32124-32131.

Zechner U, Reule M, Orth A, Bonhomme F, Strack B, Guenet, Hameister H \& Fundele R 1996 An X-chromosome linked locus contributes to abnormal placental development in mouse interspecific hybrid. Nature Genetics 12 398-403.

Zechner U, Reule M, Burgoyne PS, Schubert A, Orth A, Hameister H \& Fundele R 1997 Paternal transmission of X-linked placental dysplasia in mouse interspecific hybrids. Genetics 146 1399-1405.
Zechner U, Hemberger M, Constancia M, Orth A, Dragatsis I, Luttges A, Hameister H \& Fundele R 2002 Proliferation and growth factor expression in abnormally enlarged placentas of mouse interspecific hybrids. Developmental Dynamics 224 125-134.

Zha J, Harada H, Yang E, Jockel J \& Korsmeyer SJ 1996 Serine phosphorylation of death agonist $\mathrm{BAD}$ in response to survival factor results in binding to 14-13-3 not BCL-X(L). Cell 87 619-628.

Zhou J \& Bondy C 1992 Insulin-like growth factor-II and its binding proteins in placental development. Endocrinology 131 1230-1240.

Received in final form 26 January 2005

Accepted 31 January 2005 